\title{
Effect of Parents' Educational Level and Occupational Status on Child Glycemic Control
}

Mohammed A AlAgha, Wedyan M Majdi, Hasan M Aljefri, Mohamed Abdelfattah Ali, Abdulmoein E Alagha*, Ihab Ahmad Abd-Elhameed and Douaa Ahmad El-Derwi

Department of Pediatrics, King Abdulaziz University, Saudi Arabia

\section{Abstract}

Background: Type 1 diabetes mellitus (T1DM) is a chronic metabolic disorder. Factors affecting glycemic control, including parental higher education and occupation are important aspects in the management of the disease.

Objective: To investigate the relationship between glycemic controls measured as glycosylated hemoglobin ( $\mathrm{HbA1c}$ ) with parental higher education and occupational status in children and adolescents with T1DM.

Methods: Clinical and laboratory characteristics of 243 T1DM children and adolescents aged between 1 and 18 years visiting pediatric diabetes clinic at King Abdulaziz University Hospital (KAUH), Jeddah, Saudi Arabia were all recorded. Parents of diabetic children were interviewed. Data about their higher educational level and occupational status was assessed. Metabolic control was assessed by measuring the mean of Glycosylated hemoglobin (HbA1c).

Results: Significant difference was noticed between fathers' educational level and HbA1c $(P=0.01)$; higher educated fathers were associated with $\mathrm{HbA} 1 \mathrm{c}<7 \%(<53 \mathrm{mmol} / \mathrm{mol})$, while poor glycemic control was recorded in low educated fathers. There was no difference between HbA1c and mothers' educational level $(p=0.756)$. Regarding parental occupation and child $\mathrm{HbA} 1 \mathrm{c}$, more professional fathers have better diabetic control on their sibling ( $p=0.007$ ), while no difference on mothers' occupation $(P=0.46)$.

Conclusion: Fathers' educational level and employment status had a positive relation with children metabolic control more than mothers' education and employment status.

Keywords: Glycemic control; Type 1 diabetes; Parents; Education; Occupation

\section{Introduction}

Type 1 diabetes mellitus (T1DM) is one of the most common chronic metabolic disorders affecting children worldwide. The prevalence of (T1DM) was 109.5 per 100,000 in children and adolescents of Saudi Arabia in 2008, while it was 1.93 per 1000 in 2009 in the United States of America [1,2]. Parents involvement is the key to meet the goal of better management outcome of glycemic control and quality of life in pediatric patients $[3,4]$. One of the most important aims of health care team is to know the parents' knowledge and educational level to build up from different bases according to their information, also knowing their job and socioeconomic state to work together as a team to keep up the child glycemic control. It is well-established that the glycemic control and readmission rate of the child are affected by educational level and occupational position of the family [5]. In literature, better glycemic control in children with T1DM was found among families with higher parents' educational level, however not much is known on this topic in Saudi Arabia [6,7].

We aimed of this cross-sectional hospital-based study to assess parents' higher educational level and occupational status in relation to glycemic control among children with T1DM at King Abdulaziz University Hospital, Jeddah, Saudi Arabia.

\section{Methodology}

\section{Participants}

Our sample was taken from outpatients' diabetic clinic at King Abdulaziz University Hospital in Jeddah (KAUH) between 2013 and 2014. There were children and adolescents with T1DM between 1and 18 years of age and their caregivers. Of the 450 eligible participants only 243 , has completed the study to the end. For glycemic control, we have categorized our cohort patients into a pre-pubertal group of younger than 10 years of age and a pubertal older than 10 years of age group. All the participants' parents had the same approach of diabetic education and management including; explanation of diabetes; How to diagnose it; symptoms of hyperglycemia and how to correct it; what is the normal blood glucose; blood and urine test, insulin injection and benefit of monitoring; nutritional management and physical activity; hypoglycemia and its treatment; diabetes at school, work, during illness and emergency. In addition, each family gifted a book donation of all these information from the hospital.

\section{Data collection instruments}

Collection of the data for this retrospective cross-sectional study was during regularly scheduled medical visits, in the waiting office (patient and parent) joint 5 min interview to conduct demographic information (address, residence level, telephone number, parents educational level (elementary, high school and elementary or none) and occupational status (work or not, professional, employee and privet).

\section{Glycemic control measurement}

Glycemic control was assessed by Glycosylated hemoglobin

${ }^{*}$ Corresponding author: Abdulmoein Eid Al-Agha, Department of Pediatrics, King Abdulaziz University, Jeddah, 21452, Saudi Arabia, Tel: 00966505590459; E-mail: aagha@kau.edu.sa

Received June 28, 2017; Accepted July 03, 2017; Published July 10, 2017

Citation: AIAgha MA, MajdiWM, Aljefri HM, Ali MA, Alagha AE, et al. (2017) Effect of Parents' Educational Level and Occupational Status on Child Glycemic Control. J Pat Care 3: 130. doi: 10.4172/2573-4598.1000130

Copyright: @ 2017 AlAgha MA, et al. This is an open-access article distributed under the terms of the Creative Commons Attribution License, which permits unrestricted use, distribution, and reproduction in any medium, provided the original author and source are credited. 
(HbA1C). HbAlc is the most frequently used test to measure the glycemic control. Although the goal is age dependent, it is usually around $7.5 \%(58.5 \mathrm{mmol} / \mathrm{mol})$ in most of the children $\left({ }_{5}^{5}\right)$. For the study, we have calculated the mean $\mathrm{HbAlC}$ of 4 readings over a year period of study for each patient. Good glycemic control was defined as HbA1C values below $7(<53 \mathrm{mmol} / \mathrm{mol})$, moderate glycemic control was defined as $\mathrm{HbA1C}$ values $7-9 \%(53-74.9 \mathrm{mmol} / \mathrm{mol})$, while poor control was defined as values greater than $9 \%(>74.9 \mathrm{mmol} / \mathrm{mol})$. $\mathrm{HbA1C}$ was determined using the dimension clinic chemistry system HbA1C Kit of Dade Behring (Newark, DE 19714, USA).

\section{Statistical analysis}

SPSS software version 21 was used for analysis. Descriptive data was reported in the form of proportion, while in the quantitative data, mean and standard deviation was assessed. To assess the correlation between parents' educational level and occupational status with mean of $\mathrm{HbAlc} t$ test was performed. Significance was defined as a $\mathrm{P}<0.05$.

\section{Results}

243 children and adolescents (149 girls, 94 boys; mean age, $10.5 \pm$ 3.8 years) were included in the study. Patients who were under 10 years were $82(33.7 \%)$, while who were more than 10 years were 161 patients (66.3\%). $51.6 \%$ of the pre-pubertal age group patients had an HbAlc level $<7 \%$ ( $<53 \mathrm{mmol} / \mathrm{mol}), 39.6 \%$ had an HbAlc level 7-9\% (53-74.9 $\mathrm{mmol} / \mathrm{mol}$ ) and $27.6 \%$ of them had an $\mathrm{HbAlc}>9 \%(>74.9 \mathrm{mmol} / \mathrm{mol})$. On the other hand, the pubertal age group patients represented a $48.4 \%$ of the $\mathrm{HbAlc}<7 \%(<53 \mathrm{mmol} / \mathrm{mol})$ group, $60.3 \%$ had an $\mathrm{HbAlc} 7-9 \%$ $(53-74.9 \mathrm{mmol} / \mathrm{mol})$ and $72.4 \%$ of these patients had an HbAlc $>9$ $\%$ ( $>74.9 \mathrm{mmol} / \mathrm{mol})$. Mean HbAlc was $8.8 \pm$. Demographic data of participants according to mean of HbAlc level summarized in Table 1 .

Parents' educational and employment status play a major role in the child metabolic control. This cross-sectional study was to study the relationship between parents' educational level and employment status with the mean of HbAlc of their children as summarized in Table 2. The results showed a Significant difference between fathers' educational level and $\mathrm{HbAlc}(\mathrm{P}=0.01)$. More educated fathers are associated with good glycemic control $\mathrm{HbAlc}<7 \%(<53 \mathrm{mmol} / \mathrm{mol})$ of their children, while poor glycemic control $\mathrm{HbAlc}>9 \%(>74.9 \mathrm{mmol} / \mathrm{mol})$ was recorded in children of low educated fathers. On the other hand, there were no significant differences between $\mathrm{HbAlc}$ and mothers' educational level (collage, high school and elementary or none) $(\mathrm{p}=0.756)$. Regarding fathers' occupational status and child $\mathrm{HbAlc}$, it showed significant difference $(\mathrm{P}=0.007)$, more professional fathers have better diabetic control siblings, while no such relation was found between mothers' occupation and $\mathrm{HbAlc}(\mathrm{P}=0.46)$.

\section{Discussion}

T1DM affects the whole life of the child and his family, and the prognosis of the child can be determined to a great extent by mental and social resources of the families [8-11]. The findings from this study suggest that glycemic control among children with T1DM is significantly influenced by parents' higher educational level and occupational status. According to the present cross-sectional study, Fathers educational level and occupational position shows significant difference, children of fathers graduated from collage have lower HbAlc than those fathers with elementary certificate. Professional fathers have children with good glycemic control. Those findings are consistent with previous studies using the same method of our data collection, which have also proved that lower socioeconomic status which mainly results from unemployment of parents is related with higher HbAlc [12-15]. In contrast and according to the results of this study, neither mothers' educational level nor their occupational status have shown significant influence on their children glycemic control. In our society mothers usually combine their children during visits to pediatric diabetes clinic, where they receive an intensive program conducted by diabetic health team with each visit to clinic, while most of the time fathers don't attend to clinic and depends on mother's knowledge of diabetes. According to a study of the family interaction in pediatric diabetes in 2011, it showed that fathers almost don't step to help mothers in the management plan until glycemic control begins to deteriorate, for this reason it suggests and encourages father's active

\begin{tabular}{|l|c|c|c|}
\hline Variable & $\begin{array}{c}\text { HbA1c<7\% } \\
\text { Number of patients (\%) }\end{array}$ & $\begin{array}{c}\text { HbA1c 7-9\% } \\
\text { Number of patients (\%) }\end{array}$ & $\begin{array}{c}\text { HbA1c>9\% } \\
\text { Number of patients (\%) }\end{array}$ \\
\hline Gender & $10(10.6)$ & $32(34)$ & $52(55.3)$ \\
Male & $21(14.1)$ & $31(20.8)$ & $97(65.1)$ \\
\hline Female & & & \\
\hline Age (years) & $25(51.6)$ & $35(39.6)$ & \\
Pre-pubertal <10 & $23(48.4)$ & $54(60.4)$ & \\
Pubertal 10-18 & & & \\
\hline
\end{tabular}

Table 1: Demographic data in relation to $\mathrm{HbA} 1 \mathrm{c}$ level groups.

\begin{tabular}{|c|c|c|c|c|}
\hline Variable & $\begin{array}{c}\text { HbA1c }<7 \% \\
\text { Number of patients (\%) }\end{array}$ & $\begin{array}{c}\text { HbA1c } 7-9 \% \\
\text { Number of patients (\%) }\end{array}$ & $\begin{array}{c}\text { HbA1c }>9 \% \\
\text { Number of patients (\%) }\end{array}$ & $p$-value \\
\hline $\begin{array}{l}\text { Father's education } \\
\text { College } \\
\text { High school } \\
\text { Elementary }\end{array}$ & $\begin{array}{c}19(27.1) \\
9(5.6) \\
4(67.7)\end{array}$ & $\begin{array}{c}17(24.2) \\
39(29.8) \\
7(17.0)\end{array}$ & $\begin{array}{l}35(48.7) \\
84(63.6) \\
30(73.3)\end{array}$ & 0.01 \\
\hline $\begin{array}{l}\text { Father's occupation } \\
\text { Professional } \\
\text { Employee } \\
\text { Private }\end{array}$ & $\begin{array}{c}13(28.8 .6) \\
13(22) \\
5(3.5)\end{array}$ & $\begin{array}{l}11(24.4) \\
19(32.2) \\
33(23.7)\end{array}$ & $\begin{array}{c}21(46.8) \\
27(45.8) \\
101(72.8)\end{array}$ & 0.007 \\
\hline $\begin{array}{l}\text { Mother's education } \\
\text { Collage } \\
\text { High school } \\
\text { Elementary }\end{array}$ & $\begin{array}{c}11(15.7) \\
15(13.3) \\
5(8.2)\end{array}$ & $\begin{array}{l}16(22.8) \\
31(27.6) \\
16(26.2)\end{array}$ & $\begin{array}{l}43(61.5) \\
66(59.1) \\
40(65.6)\end{array}$ & 0.756 \\
\hline $\begin{array}{l}\text { Mother's occupation } \\
\text { Don't work } \\
\text { Work }\end{array}$ & $\begin{array}{l}27(13) \\
4(11.1)\end{array}$ & $\begin{array}{c}57(27.5) \\
6(16.6)\end{array}$ & $\begin{array}{c}123(59.9) \\
26(72.3)\end{array}$ & 0.46 \\
\hline
\end{tabular}

Table 2: Parents' educational level and occupation status in relation to $\mathrm{HbA1c}$. 
Citation: AIAgha MA, MajdiWM, Aljefri HM, Ali MA, Alagha AE, et al. (2017) Effect of Parents' Educational Level and Occupational Status on Child Glycemic Control. J Pat Care 3: 130. doi: 10.4172/2573-4598.1000130

Page 3 of 3

involvement before problems arise [16]. Comparing to other studies results, mothers' diabetes knowledge were significantly lower in mothers with a low level of education as compared to mothers with moderate level of education; mothers with greater knowledge are associated with low $\mathrm{HbAlc}$ and better metabolic control of their siblings [12-17].

Turkish study in 2010 involved 93 diabetic participants, found significant higher $\mathrm{HbAlc}$ among children of lower educated fathers $(\mathrm{p}=0.02)$ than in children of more educated fathers, however, there was no such relation between mothers' educational level and their children HbA1c $(p=0.31)$ [13]. This study has supported the influence of both fathers' educational level and occupational status on glycemic control of children with TIDM, which has as well supported by other study, but no significant influence of mothers' educational level and occupational status was found [13]. This study was conducted in a public hospital, in which the majority of patients are poor, and as shown in Table 2, working mothers comprises only the minority, while the majority doesn't work. Further research in multiple centers with more patients with different socioeconomic status and accepted diversity regarding mothers' occupational status is hence needed before generalized conclusions can be drawn and applying them on our society.

\section{Conclusion}

This study confirms the effect of parents on the glycemic control of their children. We have found positive correlation between fathers' educational level and occupational position with child HbAlc more than mothers' educational level and occupational status. We advise continuing parental involving especially in our society and fathers should be more involved in their children's diabetic management. Best glycemic outcome is evident when this involvement occurs in a collaborative and flexible manner.

\section{References}

1. Al-Herbish AS, El-Mouzan MI, Al-Salloum AA, Al-Qurachi MM, Al-Omar AA (2008) Attitude of the Saudi community towards heart donation, transplantation and artificial hearts. Saudi Med J 29.

2. Dabelea D, Mayer-Davis EJ, Saydah S, Imperatore G, Linder B, et al. (2014) Prevalence of type 1 and type 2 diabetes among children and adolescents from 2001 to 2009. JAMA 311: 1778-1786.

3. Wiebe DJ, Berg CA, Korbel C (2005) Children's appraisals of maternal involvement in coping with diabetes: Enhancing our understanding of adherence, metabolic control and quality of life across adolescence. J Pediatr Psychol 30: 167-178.

4. Ellis DA, Podolski CL, Frey M, Naar-King S, Wang B, et al. (2007) The role of parental monitoring in adolescent health outcomes: Impact on regimen adherence in youth with type 1 diabetes. J Pediatr Psychol 32: 907-917.

5. Eccleston C, Fisher E, Law E, Bartlett J, Palermo TM (2015) Psychological interventions for parents of children and adolescents with chronic illness. Cochrane Database Syst Rev 4: CD009660.

6. Gallegos-Macias AR, Macias SR, Kaufman E, Skipper B, Kalishman N (2003) Relationship between glycemic control, ethnicity and socioeconomic status in Hispanic and white non-Hispanic youths with type 1 diabetes mellitus. Pediatr Diabetes 4: 19-23.

7. Haugstvedt A, Wentzel-Larsen T, Rokne B, Graue M (2011) Psychosocial family factors and glycemic control among children aged 1-15 years with type 1 diabetes: A population-based survey. BMC Pediatr 11: 118.

8. O'Connell SM, Cooper MN, Bulsara MK, Davis EA, Jones TW (2011) Reducing rates of severe hypoglycemia in a population-based cohort of children and adolescents with type 1 diabetes over the decade 2000-2009. Diabetes Care 34: $2379-2380$

9. Hauser ST, Jacobson AM, Lavori P (1990) Adherence among children and adolescents with insulin-dependent diabetes mellitus over a four year longitudinal follow-up: II immediate and long-term linkages with the family milieu. J Pediatr Psychol 15: 527-542.

10. Tubiana-Rufi N, Moret L, Czernichow P, Chwalow J (2007) The association of poor adherence and acute metabolic disorders with low levels of cohesion and adaptability in families with diabetic children. Acta Paediatr 87: 741-746.

11. Viner R, McGrath M, Trudinger P (1996) Family stress and metabolic control in diabetes. Arch Dis Child 74: 418-421.

12. Tahirovic H, Toromanovic A (2010) Glycemic control in diabetic children: Role of mother's knowledge and socioeconomic status. Eur J Pediatr 169: 961-964.

13. Demirel F, Tepe D, Esen I, Buber N, Boztepe H (2013) Individual and familial factors associated with metabolic control in children with type 1 diabetes. Pediatr Int 55: 710-713.

14. Araujo MB, Mazza CS (2008) Assessment of risk factors of poor metabolic control in type 1 diabetic children assisted in a public hospital in Argentina. Pediatr Diabetes 9: 480-487.

15. Cameron FJ, Skinner TC, de Beaufort CE, Hoey H, Swift PG, et al. (2008) Are family factors universally related to metabolic outcomes in adolescents with Type 1 diabetes? Diabet Med 25: 463-468.

16. Jaser SS (2011) Family interaction in pediatric diabetes. Curr Diab Rep 11 480-485.

17. Stallwood L (2006) Relationship between caregiver knowledge and socioeconomic factors on glycemic outcomes of young children with diabetes. J Spec Pediatr Nurs 11: 158-165. 